\title{
Study of ELISA and antibiotic sensitivity test for Salmonella enteritidis as experimental infection in mice
}

\author{
Laheeb J. Majeed* \\ Mohammed K. Thamir ****
}

\author{
Khalid H. Znad ** \\ Haithm I. Baqir $* * * *$
}

Date of acceptance 16/10/2008

\begin{abstract}
Salmonella enteritidis one of more important as epidemiological bacteria between other salmonella types. It is very important pathologically that cause food poising and gastrointestinal tract infections. This study includes some of immunological changes that appear by ELISA test and antibiotic sensitivity test against these bacteria in mice. ELISA test results appears high immunological response happen after 3 days of inoculation, mean titration readings beginning 0.198 and the maximum mean titration after 15 days of inoculation 1.538 and begin to decrease after this time slowly to remain about 0.297 after 40 days of inoculation. An antibiotics sensitivity test result appears, this bacteria sensitive to Chloramphenicol, Ceftriaxone, Ciprofloxacin and Cotrimaxazol. Resistance to Neomycin, Streptomycin and Rifampicin, while intermediate against Ampicilin and Amoxicillin. Another test we use Vitek system to know bacterial sensitivity against to more another types of antibiotics and to confirm between some of them.
\end{abstract}

Key words: Salmonella enteritidis, ELISA test, antibiotics sensitivity test.

\section{Introduction}

Salmonella one of the more causative agent diseases that transfer by food and water. It affects human and animals. Increase food poisoning in word by salmonella one of more problems health that's because food contamination with murins feces and between infected people $[1,2]$. Increase cases of food poisoning at resent years due to $S$. enteritidis in poultry that appears healthy birds [3, 4] It has more than 2200 serotype [5]. $S$. enteritidis non-specific bacteria, affect more of one hosts of animals, laboratory animals and humans [6, 2]. It affect intestine epithelium by invasion $\mathrm{M}$ cell and lymphoid tissue of intestine like payer's patches and then distributed to other tissues by blood and lymph [2,7]. It is flagellated bacteria swimming by Run mode or by
Tumble mode [8, 9]. Adhesions of $S$. enteritidis with intestinal epithelium it is the first step infection. These adhesions happen by fimbriae on the surface of bacteria $[10,11]$ it is optimum target to immune system [12, 13]. The bacteria affects all ages of human but it more sever in children, aged and they have chronic diseases. In Iraq this bacteria isolated from dairy product industries cheese and cream [14] water, floor, insects and animal faeces [15]. Human infected by $S$. enteritidis increase in the word from 1980 that cause by egg conception [16, 17]. Chickens affected by theses bacteria in ovary and oviduct or interance bacteria to the egg from the scale $[18,19,20]$. At last $20^{\text {th }}$ years theses bacteria are the main source for infection in poultry fields and cause losses in poultry industry and serious

\footnotetext{
* Tropical unit of biological research/College of Science. Baghdad University

** College of veterinary medicine. Baghdad University

*** State company for veterinary services. Laboratories and researches division. Baghdad

**** Central health laboratory. Ministry of health. Baghdad
} 
problem in human health and poultry $[21,12,22,23]$. S. enteritidis infection in human take food poising characterized by gastroenteritis but some time take sever infection enteric fever and septicemia $[24,25]$ Salmonella transfer from animal to animal hapent in field, market and slaughter house. Shedding of bacteria increase in more stress factors, transport, crowding and water degrease cause more infection between animals and bird [26,27] animals infection by $S$. enteritidis it take form sub clinically but some of them still carrier cows suffer from fever, diarrhea, some time abortion and endometritis. Calf arthritis high mortality and sever diarrhea $[28,29]$

\section{Material and methods \\ Laboratory animals}

One hundred white balb/c mice 15-20gms weight divided to cages 6 mice for each cage.

\section{Ag preparation}

Bacterial isolation on SSagar plates and incubated at $37 \mathrm{c}^{\circ}$ for $24 \mathrm{hrs}$ and then harvested bacterial culture and washing by PBS for three times respectively by centrifuge at 3000 $\mathrm{c} / \mathrm{min}$ for five minutes for each once. Freezing and thawing for several times and centrifuging to take supernatant that contain soluble $\mathrm{Ag}$ and incubated in $-20 c^{\circ}$ at using [30]. Determination protein concentration of $\mathrm{Ag}$ depend on [31] protein combination with collar agent pirogallolo Red-Molibdato in acidic solution to compound collar complex that resemble with protein concentration. Mixed component in circular system vortex and incubate at $37 \mathrm{c}^{\circ}$ for 5 minits. Mixed again and read extinction against blank by spectrophotometer at wave length 600 $\mathrm{nm}$ and application this formula

Total protein liquor $(\mathrm{mg} / \mathrm{dl})=\frac{\text { E sample }}{- \text { ESTD }^{---} \times \text {C.STD }}$

E=Extinction

C. $S T D=$ standard conc. $50 \mathrm{mg} / \mathrm{dl}$

Serum Preparation

Serum prepared from blood sampling of mice that used in test as this table of time

\begin{tabular}{|l|l|l|l|l|l|l|l|l|l|l|}
\hline Day & Day & Day & Day & Day & Day & Day & Day & Day & Day & Day \\
\hline 3 & 6 & 9 & 12 & 15 & 18 & 21 & 24 & 27 & 30 & 40 \\
\hline
\end{tabular}

Check board titration

For estimate optimum concentration of Ag that recognize positive and negative results and optimum dilution of serum used titration by several concentration of $\mathrm{Ag}$

\begin{tabular}{|l|l|l|l|l|}
\hline $1: 40$ & $1: 80$ & $1: 160$ & $1: 320$ & $1: 640$ \\
\hline
\end{tabular}

And several dilution of serum positive and negative control

\begin{tabular}{|l|l|l|l|l|}
\hline $1: 100$ & $1: 200$ & $1: 300$ & $1: 400$ & $1: 500$ \\
\hline
\end{tabular}


And determination optimum concentration of $\mathrm{Ag}$ and serum dilution by test best reading that differentiate between positive and negative.

\section{Positive control}

Serum of 10 infected mice presented by intraperitoneal inoculation of $s$. enteritidis and give positive results of bacterial isolation from these mice in blood culture.

\section{Negative control}

Serum of 10 non infected mice presented and give negative result in blood culture.

Cut of point determent by mean optical density (OD) of negative control added to multiply of standard deviation [32].

\section{Procedure}

$200 \mu \mathrm{l}$ of $\mathrm{Ag}$ about $1.5 \mu \mathrm{g} /$ well after dilution 1:40 with coating buffer for each well of micro plate titration board, covering and incubated at $4 c^{\circ}$ to night. Wash plate with washing buffer four times dried with drying paper. Put $200 \mu 1$ of blocking buffer and incubated at $4 \mathrm{c}^{\circ} 24 \mathrm{hrs}$ washing four times and put $200 \mu \mathrm{l}$ of diluting serum $200: 1$ with diluting buffer for each well of plate, incubated for one hour at $37 \mathrm{c}^{\circ}$. Wash five times and adding $100 \mu \mathrm{l}$ of diluting conjugate $1000: 1$ for each well and incubate for one hour at $37 \mathrm{c}^{\circ}$. Washing and adding $100 \mu 1$ of substrate for each well of plate and putting in dark place at room temperature. Stopped activation by adding $50 \mu \mathrm{l}$ of HCL.
Result reading by ELISA reader spectrophotometer at wave length $450 \mathrm{~nm}$.

\section{Salmonella enteritidis antibiotic sensitivity test}

Depend on [33] and test nine types of different antibiotic with $S$. enteritidis type D by using specific discs

\section{Method}

Prepared bacterial suspension with normal saline and cultured on Muller Hinton agar with equal distribution. Discs distributed at five discs for each plate, incubated at $37 \mathrm{c}^{\circ}$ for $24 \mathrm{hrs}$. Measuring antibiotic sensitivity depending standard tables. Also we depend on BioMerieux Vitek system that is important in identification and antimicrobial susceptibility testing and for rapid results.

\section{Results}

Depended on ELISA test to determent a level of immune response against $S$. enteritidis at limited time table. The results estimate the best serum dilution that differentiate between negative and positive is 1:200, the optimum antigen concentration is $1: 40$ and conjugate dilution is $1: 1000$ mean of OD negative control 0.22 and standard deviation 0.02 that the cut of point for reader 0.26 . The maximum, minimum and means OD of serum samples at days for each sample as in table (1). 
Table (1) maximum, minimum and means OD of ELISA test for each case at determent time

\begin{tabular}{|l|l|l|l|l|}
\hline Group & Days after injection & Maximum & Minimum & Means \\
\hline 1 & 3 & 0.213 & 0.185 & 0.198 \\
\hline 2 & 6 & 0.297 & 0.220 & 0.256 \\
\hline 3 & 9 & 0.634 & 0.542 & 0.595 \\
\hline 4 & 12 & 1.012 & 0.924 & 0.972 \\
\hline 5 & 15 & 1.643 & 1.430 & 1.538 \\
\hline 6 & 18 & 1.580 & 0.972 & 1.319 \\
\hline 7 & 21 & 1.607 & 0.952 & 0.853 \\
\hline 8 & 24 & 0.956 & 0.210 & 0.535 \\
\hline 9 & 27 & 0.665 & 0.210 & 0.438 \\
\hline 10 & 30 & 0.453 & 0.185 & 0.307 \\
\hline 11 & 40 & 0.439 & 0.210 & 0.297 \\
\hline
\end{tabular}

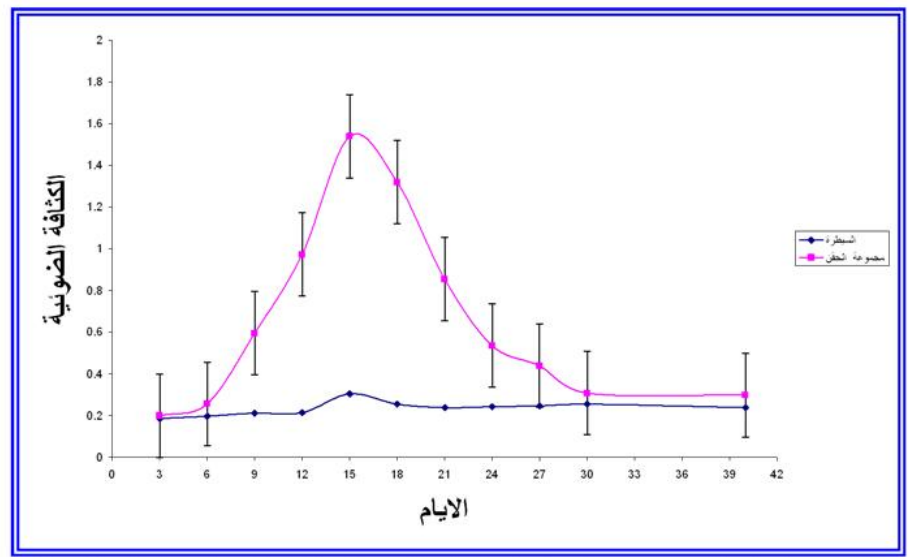

Figure (1) optical density distribution for infected mice serum by intraperitoneal rote

Table (2) type, concentration and sensitivity of $S$. entritidis for some antibiotics

\begin{tabular}{|l|l|l|l|l|}
\hline No & Antibiotic & Symbol & Concentration & $\begin{array}{l}\text { Type } \\
\text { resistant }\end{array}$ \\
\hline 1 & Ampicillin & Am & $10 \mathrm{mg}$ & I \\
\hline 2 & Chloramphenicol & C & $30 \mathrm{mg}$ & S \\
\hline 3 & Neomycin & NE30 & $30 \mathrm{mg}$ & R \\
\hline 4 & Streptomycin & S10 & $10 \mathrm{mg}$ & R \\
\hline 5 & Ceftriaxone & CRO30 & $30 \mathrm{mg}$ & S \\
\hline 6 & Ciprofloxacin & CIP5 & $5 \mathrm{mg}$ & S \\
\hline 7 & Rifampicin & RP5 & $5 \mathrm{mg}$ & R \\
\hline 8 & Cotrimoxazole & TS25 & $25 \mathrm{mg}$ & S \\
\hline 9 & Amoxicillin & A25 & $25 \mathrm{mg}$ & I \\
\hline
\end{tabular}

Disc: mast group LTd. Company UK
R: Resist
$\mathrm{S}$ : Sensitive
I: intermediate 
Table (3) sensitivity test of $S$. entritidis for some of antibiotic by using BioMerieux Vitek system

\begin{tabular}{|l|l|l|l|}
\hline No & Antibiotic & Mic $\boldsymbol{\mu g} / \mathbf{m l}$ & Sensitivity \\
\hline 1 & Ampicillin & 1 & S \\
\hline 2 & Aztreonam & $8 \geq$ & S \\
\hline 3 & Cefazolin & $8 \geq$ & S \\
\hline 4 & Cefepime & $4 \geq$ & S \\
\hline 5 & Cefotetan & $16 \geq$ & S \\
\hline 6 & Ceftazidime & $8 \geq$ & S \\
\hline 7 & Ceftriaxone & $8 \geq$ & S \\
\hline 8 & Ciprofloxacin & 1 & S \\
\hline 9 & Gentamycin & 4 & S \\
\hline 10 & Imipenem & $4 \geq$ & S \\
\hline 11 & Levofloxacin & 2 & S \\
\hline 12 & Piperacillin / tazobadem & $8 \geq$ & S \\
\hline 13 & Tobramycin & 4 & S \\
\hline 14 & Trmethsulf & $10 \geq$ & S \\
\hline
\end{tabular}

Mic $=$ minimum inhibition concentration

\section{Discussion}

Antimicrobial resistant against salmonella important to know the development of this resistant and distribution and how to control of this bacteria by drug selecting and optimum dose [34,35] this results appear multi resistance for several antibiotic that use in hospitals and appear sensitive for others. The cause of this multi resistance is trance from resistance bacteria to sensitive that alive in same environments by genes on conjugated plasmid [36]. Some of this bacterial resistance related with $\mathrm{R}$ factor that lead to trance multiple resistance of antibiotic at some time and that happens mostly in bacteria that cause diarrhoea [37,38,39]. Adding antibiotic randomly to animals feed to growth stimulation and increase production cause bacterial resistance in many countries [40,41] now most of salmonella species resistance to many antibiotic and cause sever disease in AIDS patients or in organs transplantation [7].
Used white mice in this research because it sensitive to infection and give high immune response. Depend intra peritoneal rout of injection to wide spread bacterial dissemination to different organs and used ELISA test because it is high sensitive and high specific [42]. Alive bacteria have high stimulation with one dose and have whole antigens and have ability to multiplication and toxins production to attack different body tissues [43]. Increase Abs titters due to $\mathrm{T}$ helper lymphocytes stimulation and production sensitive plasmid cells and memory lymphocytes.

\section{References}

1. Schiefer, B., and Loew, F.M. 1978. Amebiasis and salmonellosis in a woolly monkey (Lagothrix). Vet. Pathol., 15:428-431.

2. Shahin, A. 2005. Investigation of the humoral and cellular immune responses of chickens to Salmonella typhimurium live vaccine. Ph.D.Thesis. Faculty of 
Veterinary Medicine. LudwigMaximilians-University, Munich.

3. Mouchet, J. 2000. Airport malaria: A rare disease sties poorly understood. Eurosurveillance. France. 5 (7/8):75-88.

4. Chang J., Pang E., He H. and Kwang J. 2008.Identification of novel attenuated Salmonella Enteritidis mutants. FEMS Immunology \& Medical Microbiology 53 (1): 26-34.

5. Bermner, A. and Johnston, M. 1996. Poultry meat and inspection, Food poisoning associated with poultry meat. pp. 149-169.

6. FSRIO-food safety research information office. 2004. A focus on salmonella.

7. Hughes, E.A. and Galan, J.E. 2002. Immune response to Salmonella: Immunity, 16(3): 325-328.

8. Berg, H.C. 1993. Random walks in biology. Princeton University Press, Princeton, New Jersey. p. 164.

9. Grijspeerdt K. 2001. Modelling the penetration and growth of bacteria in eggs. Food Control, 12 (1): 7-11.

10. Thorns, C. J. 1995. Salmonella fimbriae: Novel antigens in the detection and control of Salmonella infections. Br. Vet .J. 151:643-659.

11. Ugorski ,M.; Kisiela, D. and Wieliczko, A. 2001. Fimbriae Salmonella enterica serovar Enteritidis. Medycyna Wet. 57:714-718

12. Kuczkowski, M.; Wieliczko, A.; Kisiela, D.; Mazurkiewicz, M. and Ugorski, M. 2004. Cellular response and protective effect in hens immunized with Salmonella enteritidis recombinant fimbrial SefA, FimA and AgfA proteins. Bull. Vet. Inst. Pulawy. 48: 375382.

13. Deng, S.X.; Cheng, A.C.; Wang, M.S.; Cao, P.; Yan, B.; Yin, N.; Cao, S.and Zhang, $Z$. 2008. Quantitative studies of the regular distribution pattern for Salmonella enteritidis in the internal organs of mice after oral challenge by a specific real-time polymerase chain reaction. World $\mathrm{J}$ Gastroenterol., 14(5): 782-789.

14. Rashid, R. and Al-Hindawi, N. 1979. Presence and distribution of Salmonella species in some local foods from Baghdad city, Iraq $\mathbf{J}$. Food Prot., 42:877-880.

15. Schneider, K.R.; Goodrich, R.M. and Waithe, S.Z. 2000. Preventing Foodborne Illness: Sallmonellosis. I.F.A.S., University of Florida.

16. Boonmar,S.; Bangtrakulnonth,A; Pornrunangwong, S.; Terajima,J.; Watanabe,H.; Kaneko,K. and Ogawa,M. 1998. Epidemiological analysis of Salmonella enteritidis isolates from human and broiler chickens in Thailand by Phage Typing and Pulsed-Field Gel Electrophoresis. J. Clin. Microbiol., 36(4):971-974.

17. White, P. L.; Baker, A. R. and James,W.O. 1997. Strategies to control Salmonella and Campylobacter in raw poultry products. Rev. Sci. Tech. Off. Int. Epiz., 16 (2): 525-541.

18. Brown, A. 1999. Eggs Understanding Food: Principles and preparation. Wadsworth, Thomson Learning, Stamford, U.S.A. pp. 238-254.

19. Chen J., Clarke, R.C. and Griffiths, M.W. 1996. Use of luminescent strains of Salmonella enteritidis to monitor contamination and survival in eggs. Journal of Food Protection., 59 (9): 915-992

20. Cogan T.A., Domingue G., LappinScott H.M., Benson C.E., Woodward M.J. and Humphrey T.J. 2001. Growth of Salmonella enteritidis in artificially contaminated eggs: The effects of inoculums size and suspending 
media. Inter. J. Food Microbiol., 70 (1-2): 131-141

21. Bennasar, A.; de Luna, G.; Cabrer, B. and Lalucat, G. 2000. Rapid identification of Salmonella typhimurium, S. enteritidis and S. virchow isolates by Polymerase Chain Reaction based finger printing methods. Inter. Microbiol., 3:31-38.

22. Rabsch, W.; Tschpe, H., and Bumler, A.J. 2001.Non-typhoid salmonellosis: emerging problems. Microbes Infect. 3:237- 247.

23. Zee, H.; Van der, and Boer, E. 1997. Salmonella species. and Salmonella enteritidis in poultry products and raw egg material in the Netherlands, Proc. Inter. Symp. Salmonella and salmonellosis. Ploufragan, France. p. 377.

24. Darwin, K.H. and Miller,V.L. 1999 Molecular basis of the interaction of Salmonella with the intestinal mucosa. Clin. Microbiol. Rev., 12(3):405-428.

25. Mishu, B.; Koehler, J. and Less, L.A. 1994. Outbreaks of Salmonella enteritidis infections in the United States, 1985-1991. J. Infect. Dis., 169:547-552.

26. Quinn, P.J.; Carter, E.M.; Markey, B.K. and Carter, E.R. 1998. Enterobacteriaceae. In: Clinical Veterinary Microbiology. Mosby, London, UK. PP. 209-236.

27. Takahashi,T.; Koehler,J.; Swenson,P. and Duchin,J. 2004. Evaluation of a public health Salmonella surveillance system in King County, Washington. Am. J. Infect. Control, 32:7-11.

28. Centers for Diseases Control and Prevention (CDC). 2003. Salmonellosis .U.S. Department of Health and Human Services, CDC, Atlanta, Ga. (Internet)

29. Zapor, M. and Pooley,D.P. 2002. Salmonellosis. eMedicine World
Medical Library pp.1-14. eMedicine .com,Inc.

30. Cruickshank, R.; Duguid, J.P.; Mormion, B.P. and Swain, R.H.A. 1975. Medical Microbiology. In: The Practice of Medical microbiology. 12th ed. Edinburgh, Churchill Livingston. London.

31. Watanabe, N. 1986. Clinical Chemistry. 32, 1551. Giesse Diagnostics Co. Roma. Italy.

32. Lefkovits, I. 1997. Immunology methods manual the comprehensive source book of techniques vol.1 Academic press. Newyork. U.S.A

33. World Health Organization (WHO) 1991. Basic Laboratory Procedures in Clinical Bacteriology. Geneva. London.

34. 34. Jalal, S.; Clofu, O.; Hoiby, N.; Gotoh, N. and Wrtlind, B. 2000. Molecular mechanisms of flouroquinolone resistance in Pseudomonas aeuroginosa isolates from cystic fibrosis patients. Antimicrob. Agents. Chemother., 44:710-712.

35. Ziha- Zariti, I.; Ltanes, C.; Kohler, J.; Pechere,W. and Plesiat, P. 1999. In Vivo, emergence multi drugs resistant mutants of Pseudomonas aeuroginosa over expressing the active efflux system Mex A- Mex B- Opr N. Antimicrob. Agents Chemother. 43:287-294.

36. Hoge, C.W.; Salim, D.R.; Echeverria, P.; Rajab, R.; Herman, J.E. and Cross, J.H. 1996. Epidemiology of diarrhea among expatriate resident living in a highly endemic environment. J. Am. Vet. Med. Ass., 275: 533-538.

37. Ryder, R.W.; Blake, P.A.; Murlin, A.C.; Carter, G.P.; Pollard,R.A.; Merson,N.H.; Allen, S.D. and Brenner,D.J. 1980. Increase in antibiotic resistance among isolates of Salmonella in United States, 
1967-1975. J. Infect. Dis., 142(4): 485-490.

38. Smith, H.R.; Grindly, N.D.; Hampheryes, G.O. and Anderson, K.O. 1973.Salmonella and Campylobacter. J.Bact. 115:623.

39. Sur, D.; Niyogi, S.; Sur, S.; Tackeda, Y. and Nair, G. 2003. Multidrug resistant Shigella dysenteriae typel fore run - ners of anew epidemic strain in eastern India. Emerg. Infect. Dis. 9(3): 404-405.

40. Benenson, M.I. 1990. Salmonellosis. In: Control of Communicable Disease in Man. 15th ed. Am. Pub. Hilth. Asso.
41. Threllfall, E.J.; Ward, L.R.; Ashley, A.S. and Rowe, B.K. 1980. Plasmid encoded Trimethoprim resistance in multiresistant epidemic Salmonella typhimurium phage type 204 and 193 in Britin. B.M.S.pp. 280-290.

42. Al-Mounas, M.S.T 1998 .Epidemiological and Seroimmunological studies on hydatid disease in Basrah (Southern Iraq). Ph.D. Thesis, College of Education, University of Basrah

43. Goldsby, R.A.; Kindt,T.J. and Obsorn, B.A.2000. Vaccine. In: Immunology. Curr.Top. Microbiol., 48:20-42. 

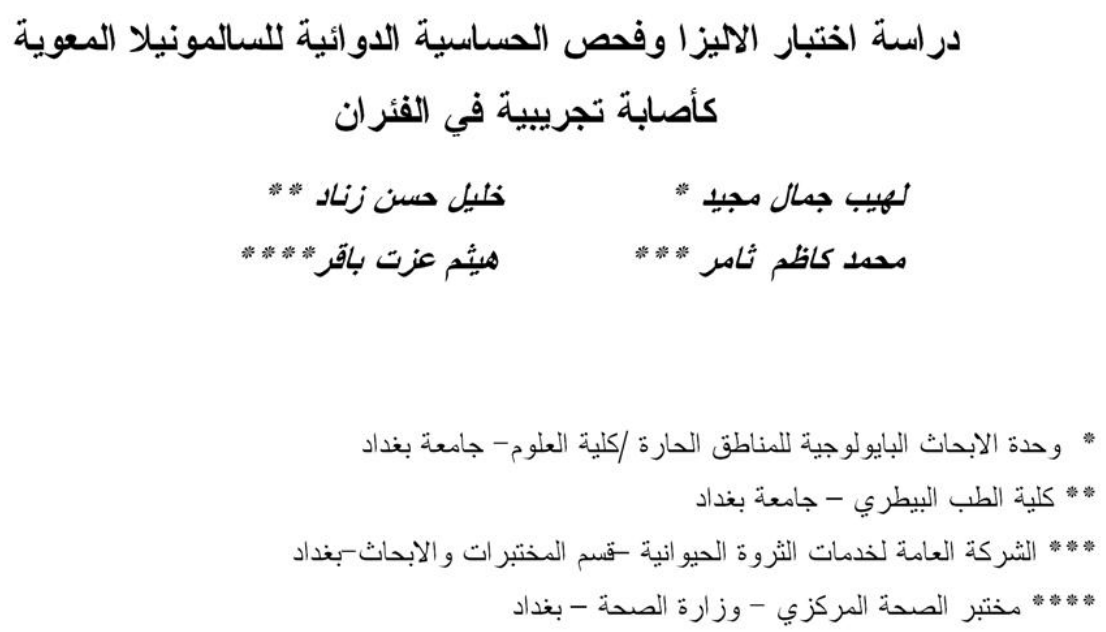

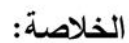

جرثومة Salmonella enteritidis و واحدة من أهم الجر اثيم الوبائية من بين أنواع السالمونيلا الأخرى و

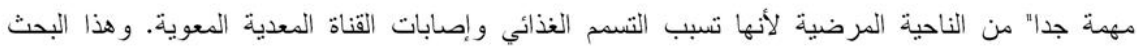

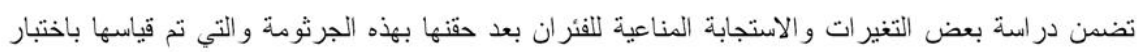

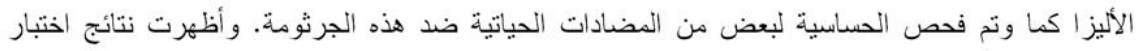

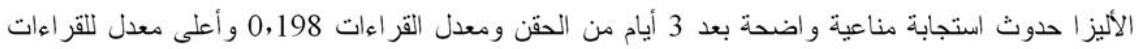

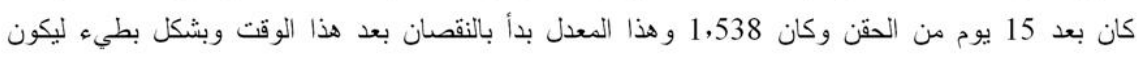

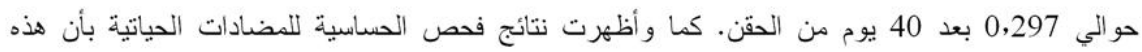

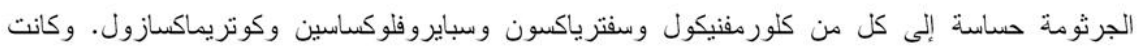

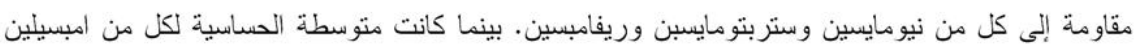

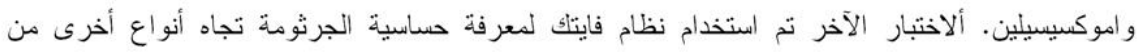
المضادات الحياتية وللمقارنة مع بعضها.

الكلمات المفتاحية: السالمونبلا المعوية ، اختبار الالبزا، فحص الحساسبة. 